International Journal of Engineering \& Technology, 7(4.38) (2018) 1098-1100
International Journal of Engineering \& Technology
SPC
Website: www.sciencepubco.com/index.php/IJET
Research paper

\title{
Conceptual Aspects of Development Banks
}

\author{
Galina Alekseevna Bunich ${ }^{1 *}$, Yuriy Aleksandrovich Rovenskiy ${ }^{2}$, Julia Tambievna Akhvlediani², Elena Anatolievna \\ Zvonova ${ }^{1}$ \\ 1 "Financial University under the government of the Russian Federation", 125993, Moscow, Leningrad Ave., d. 49 \\ 2 "Plekhanov Russian University of Economics", 117997, Moscow, Stremyanny Lane, 36 \\ *Corresponding author E-mail: galina_bunich@mail.ru
}

\begin{abstract}
The development of national and regional economies in the conditions of financial and economic instability determines special conditions for the formation of financial resources.

The innovative improvement of national economies of developing countries has substantiated active evolvement of financial institutions such as development banks.

The formation and evolvement of development banks is going through a new phase. These are not the financial institutions that were formed by the metropolis countries after the collapse of the colonial system. They have different mission, goals, principles, methods and instruments.

Modern development banks prioritize the issues of financing socio-economic projects, crediting traditional sectors of the economic activity, and, above all, the infrastructure development of regions, the construction of transport systems, and energy supply. Today one of the most important areas of the development banks' credit activity is the formation of a loan portfolio for small and medium-sized businesses.

With all the diversity of development banks substantiated by historical and economic characteristics of countries and regions, the UNO and the World Bank Group distinguish common features, principles and peculiarities. These peculiarities and unique functions of development banks are found in international standards that define a special status of development banks as financial institutions.
\end{abstract}

Keywords: international development banks, long-term crediting, investments, top priority financing objectives, business principles, conceptual aspects, activity integration and cooperation.

\section{Introduction}

Development banks are unique financial institutions that emerged due to the collapse of the colonial system in the 1950-1960s. At this stage, development banks were initiated by the metropolitan countries that strived to preserve the financial dependence of the former colonies and to use their mineral and natural resources.

A new stage in the formation and evolvement of development banks started in the 2000s. A prerequisite for this evolvement was the formation of a bloc of developing countries that have embarked on the course of market reorganization of the economy. These are development banks, not only national, but, above all, regional - international, that become the center for implementing socio-economic programs in the region.

The innovative development of the economy and high cost of regional socio-economic projects determine the dynamics of forming and evolving development banks.

In this regard, it is urgent to study strategic aspects of development banks.

\section{Results}

According Experts from international financial institutions, such as the IMF, the World Bank Group, the UNO, and the Bank for International Settlements study the activity of development banks and identify their evolvement peculiarities and trends.
The materials of the UNO expert session identify the conceptual aspects of the development banks' strategy (Figure 1).
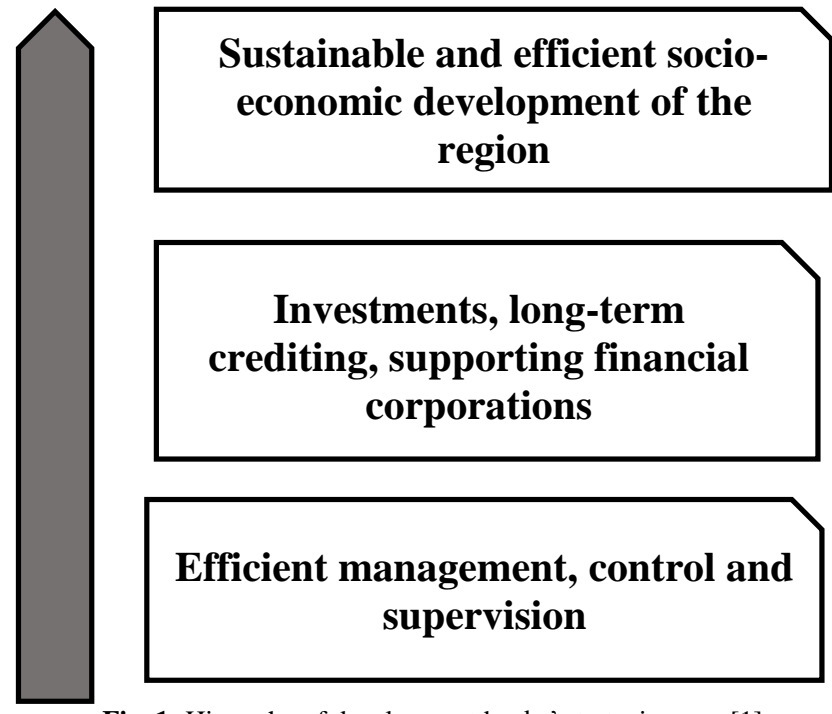

Fig. 1: Hierarchy of development banks' strategic areas [1]

According to the figure, the activity of development banks is based on the criteria determining efficient management of the bank, professional and even expert knowledge of development bank specialists who suggest the formation of strategic and current 
plans of the activity and management of the bank based on dynamic studies.

On the one hand, the regulations of the bank primarily meet the interests of the state (a group of states of the region), but, on the other hand, they are influenced by the global financial market, as well as objectives of the bank financial management that determine the required terms and conditions for the efficiency, sufficient liquidity, financial sustainability, and investment activity.

The second (or derivative) component of the development bank's activity determines the main areas of activity that, as a rule, come with research, projects' evaluation and formation, assistance, attraction of financial resources, analysis and control, support and assistance in the implementation of plans.

The highest productive aspect of development banks is to ensure sustainable and efficient socio-economic development of the region.

Thus, the highest goal of development banks is the result characterizing the optimality of the selected programs and the efficiency of their implementation. The development banks' activity results in the formation of a favorable socio-economic environment in the region, characterized by a high level of evolvement of top priority sectors of the economy, infrastructure, environmental and social components. At the same time, for all the above parameters it is necessary to provide not only the efficient state, but also sustainable development [5, 6].

Thus, when performing the stages that constitute top priority strategic principles of the development banks, the conditions for achieving the strategic goal are formed.

The hierarchy of strategic areas of development banks conceptually fully describes the efficient activity of development banks. However, in practice, not all elements will be fully implemented.

In the 21 st century, top priority tasks of development banks are the following:

Participation in project studies and project financing,

Participation in administering state programs,

Analysis of the economic efficiency of investments,

Mobilization of credit and investment resources to implement state and export programs,

Technical assistance, modeling and technology transfer,

Support in attracting resources of the international financial market,

Venture financing of projects and the formation of banks' information databases,

Consulting and investment services,

Leasing, insurance,

Development and support of small and medium-sized business,

Participation in restructuring the regional economy, the development of capital markets, and

Formation of educational centers of entrepreneurship.

Development banks are crucial for the economy development, and support financially those industries and areas of activity that are not interesting for commercial banks.

Further evolvement and modernization of development banks will allow regional corporations to access cheap credit resources and stimulate their evolvement.

In the 21 st century, development banks will continue to take an active part in project financing, administering credit programs, providing technical assistance and technology transfer, implementation of pre-investment, feasibility and project studies, financing small and medium-sized enterprises, and the improvement of human resources.

Competence, flexibility, adaptability and innovative potential of development banks within their political, economic and social environment will further determine their importance for the development of countries and regions where they operate.

Despite the important role of development banks in the economies of countries and regions, it is impossible to classify them clearly and unambiguously. Development banks are different, and in various countries they differ by many characteristics, such as

Form of ownership (state, private, mixed),

Goals and tasks (development banks with narrow specialization, universal development banks),

Financing mechanisms (deposit and investment banks),

Target industries, instruments and financing mechanisms,

Crediting mechanisms (direct or through intermediary services),

Interest rates (subsidized or market),

Supervision and regulation of the activity (a special system or a system applied to private credit organizations),

Structure of corporate management (the number of government representatives in the board of directors), and

Disclosure (confidentiality) of information on financial programs and results of development banks.

Most development banks in the world are fully owned by the state (Figure 2). $74 \%$ of all development banks are owned by the state, $21 \%$ of them have mixed form of ownership, which implies private ownership along with the state one, and 5\% (11 development banks) are privately owned.

\section{Development banks}

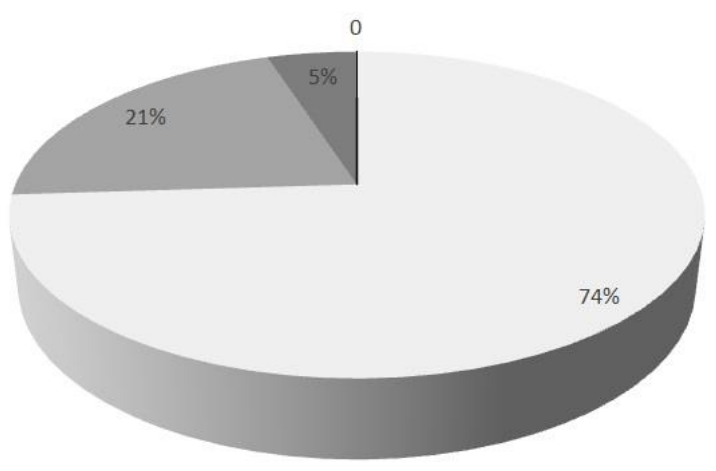

State banks Banks partially owned by the state $\quad$ Private banks

Fig. 2: Classification of development banks by their ownership type [2]

Unlike commercial banks, the independence of development banks in making credit and investment decisions is limited by a mandate.

The mandate of the development bank should be clearly defined, tied to the identified market risks and should not imply vague formulations. The bank must be coordinated with other development banks, and there must be no competition with commercial banks due to the monopoly position of the development banks in the national or regional economy.

Despite many goals and tasks, development banks can be divided into two groups:

- Universal development banks that do not have a clearly limited area of activity,

- Special banks, i.e. banks with narrow specialization, the task of which is to finance exclusively certain sectors of the economy (agriculture, small and medium-sized business) or carry out certain operations (export-import).

Tasks of universal development banks are formulated as "supporting the economic development of the country", "improving the well-being of citizens", etc.

As a rule, there are three goals universal development banks must achieve (Figure 3):

Economic development, while maintaining the priority of infrastructure projects,

- Social development, and

- Regional integration. 


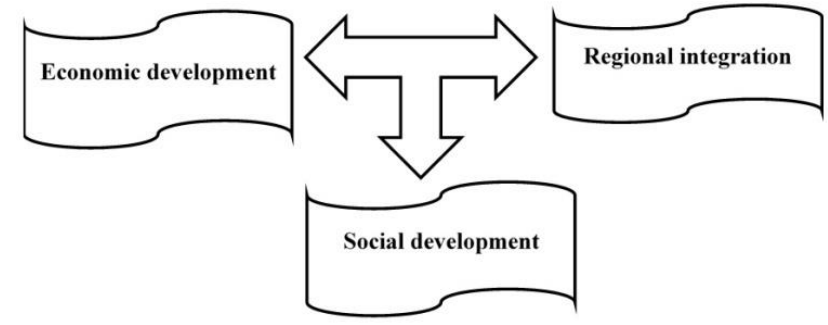

Fig. 3: Goals of universal development banks

It Special objectives of development banks vary, but in recent years they have become the leading ones:

- Financing sustainable development, including rural development,

- Financing adaptation to the climate change,

- Green economy, including alternative energy.

\section{Top priority specializations of development banks}

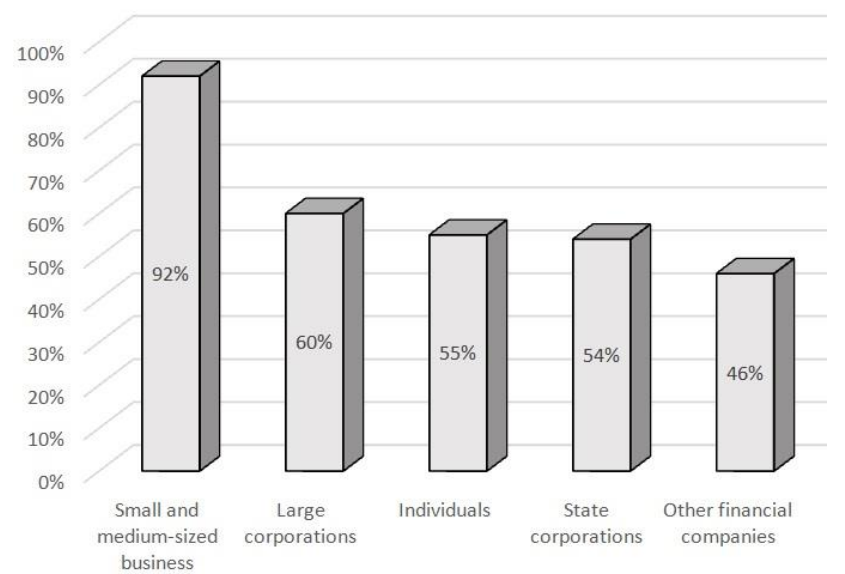

Fig. 4: Top priority specialization of development banks [3, 4]

It is possible to note that regardless of the ownership form and the strategic tasks of the development bank, almost all of them finance small and medium-sized businesses (Figure 4). This is due to the fact that in developing countries financing of this segment is one of the most acute problems. Even in developed countries such as Germany and Canada, one of the main tasks of local development banks is to finance small and medium-sized businesses.

\section{Conclusion}

A new stage in the formation and activity of development banks all over the world is characterized by particular activity, which is primarily due to the need of developing regions in evolving the transport infrastructure, implementing innovative programs for developing top priority sectors of the economy, and acute socioeconomic problems.

Today, development banks are owned mainly by the state. They implement marginal state socio-economic projects that are not interesting for commercial banks. Therefore, even national development banks do not compete with commercial banks.

One of the peculiarities of the loan portfolio of development banks is financing of entrepreneurial activities of small and mediumsized businesses, state corporations and innovative start-ups.

Regional development banks contribute to the integration and cooperation of national economies in the region, and ensure the solving of the general regional problems related to the evolution of the developing countries.

The terms and conditions of the advanced innovation development, socio-political instability, and economic sanctions against developing countries substantiate the objective need to improve principles, methods and instruments of development banks.

\section{References}

[1] Rethinking the Role of National Development Banks//UN Department of Economic and Social Affairs- 2005.

[2] The World Bank. According to the new report of the World Bank, the developing world share of global investment to triple by 2030 . http://www.vsemirnyjbank.org/ru/news/pressrelease/2013/05/16/developing-world-share-of-global-investmentto-triple-by-2030-says-new-world-bank-report. Revised May 2013 Accesed September, 16, 2018

[3] Encyclopaedia Britannica. Development bank http://www.britannica.com/topic/development-bank. Accesed September, 16, 2018

[4] European Investment Bank. The EU bank. http://www.eib.org/en/about/index.htm Accesed September, 16 , 2018

[5] G. Bunich, Yu. Rovtnski, L. Dashkov, Factoring development: theory and practice has been accepted, Espacios 39(18) 2018 http://www.revistaespacios.com/a18v39n19/a18v39n19p33.pdf

[6] Yu.A. Rovenskiy, G.A. Bunich, Dengi, kredit, banki [Money, credit, banks], Prospect, Moscow, 2016. 